\title{
Estimasi Keadaan Cuaca di Kota Pontianak Menggunakan Aplikasi Jaringan Syaraf Tiruan (JST) Algoritma Hopfield
}

\author{
Retnawati, Andi Ihwan, Muh. Ishak Jumarang \\ Program Studi Fisika FMIPA UNTAN \\ Email : Redzna_zhaa@yahoo.com
}

\begin{abstract}
Abstrak
Telah dilakukan penelitian tentang estimasi keadaan cuaca, menggunakan Jaringan Syaraf Tiruan Algoritma Hopfield. Parameter yang digunakan dalam penelitian ini adalah suhu udara, kelembaban udara, tekanan udara, dan arah angin jam-jaman pada bulan Mei, Juni, dan November 2012. Berdasarkan simulasi model yang dilakukan, diperoleh nilai estimasi keadaan cuaca pada bulan Mei sangat baik (82\%), dan pada bulan Juni dan November masing-masing pada tingkat ketepatan baik (79\% dan 75\%).
\end{abstract}

Kata Kunci: Algoritma Hopfield, Cuaca, Jaringan Syaraf Tiruan

\section{Pendahuluan}

Cuaca adalah keadaan udara pada saat tertentu dan di wilayah tertentu yang relatif sempit pada jangka waktu yang singkat. Cuaca pada saat pagi hari, siang, sore atau malam hari keadaannya bisa berbeda-beda untuk setiap tempat serta setiap jamnya.

Informasi cuaca dapat berupa prakiraan cuaca. Beberapa metode prakiraan cuaca telah dikembangkan hingga saat ini, salah satunya adalah dengan menggunakan Jaringan Syaraf Tiruan (JST). JST dapat digunakan untuk pengenalan pola dan peramalan.

Penelitian sebelumnya (Ernawati, 2009) menggunakan JST metode Hopfield untuk prakiraan cuaca di Cilacap dengan menghasilkan output yang tepat, prakiraan cuaca di Kota Cengkareng dengan menghasilkan prakiraan cuaca 76\% dan 86\% (Irmawan, 2011), serta penyelasaian shortest path problem dengan JST Hopfield (Hasanah, 2007).

\section{Landasan Teori}

\subsection{Keadaan Iklim Kota Pontianak}

Kota Pontianak memiliki hutan hujan tropis dengan suhu yang tinggi. Suhu tinggi diikuti pula dengan kelembaban udara yang tinggi yang meyebabkan tingginya intensitas curah hujan.

\subsection{Cuaca}

Cuaca terbentuk dari gabungan unsur cuaca yaitu suhu udara, kelembaban udara, tekanan udara, angin dan curah hujan. Kondisi iklim tropis di Indonesia yang memiliki ciri yaitu suhu udara yang tinggi, kelembaban tinggi, dan curah hujan yang tinggi.

Cuaca cerah adalah cuaca yang menunjukkan langit dalam kondisi terang, sinar matahari memancar terang tetapi tidak begitu terasa panas. Pada saat cuaca cerah jumlah awan yang menutupi langit kurang dari separuh hingga separuh bagian langit dan tidak terjadi hujan.

Cuaca berawan menunjukkan bahwa di langit banyak terdapat awan yang terlihat berjalan karena didorong oleh angin. Awan merupakan kumpulan uap air yang terdapat di udara.

Fenomena hujan terjadi karena adanya proses penguapan air di bumi oleh matahari. Uap air kemudian akan dibawa oleh angin hingga membentuk gumpalan-gumpalan awan. Ketika terbawa angin, awan-awan akan mengalami kondensasi, partikel-partikel uap air dari awan akan menjadi gumpalan-gumpalan air yang kemudian terjatuh ke bumi dalam bentuk tetesan air. Tetes air hujan memiliki diameter $0,5 \mathrm{~mm}$ dan intensitasnya lebih dari 1,25 $\mathrm{mm} / \mathrm{jam}$ (Asdak, 1995).

Suhu udara merupakan keadaan panas atau dinginnya udara. Suhu udara terjadi karena dampak dari adanya radiasi panas matahari yang diterima oleh bumi. Pada hari yang cerah, radiasi cepat memanaskan daratan dan kemudian daratan memanaskan udara di atasnya. Pada malam yang cerah terjadi pula pelepasan panas yang berasal dari bumi yang menyebabkan terjadinya pendinginan dengan cepat di permukaan (Horn dan Trewartha, 1995)

Kelembaban udara digunakan untuk menyatakan banyaknya kandungan uap air dalam udara. Setiap saat ada uap air yang masuk dan dilepas oleh atmosfer. Uap air ditransfer ke udara melalui proses penguapan karena panas matahari.

Tekanan udara adalah tekanan yang diberikan udara setiap satuan luas bidang datar dari permukaan bumi sampai batas atmosfer. Tekanan udara semakin rendah apabila semakin tinggi dari permukaan laut. (Arpan dkk, 2004). 
Angin merupakan udara yang bergerak karena adanya perbedaan tekanan di permukaan bumi. Perubahan panas antara siang dan malam merupakan gaya gerak utama sistem angin harian, karena beda panas yang kuat antara udara di atas darat dan laut. Pada siang hari angin bergerak lebih cepat daripada di malam hari (Arpan dkk, 2004).

\subsection{Jaringan Syaraf Tiruan (JST) Algoritma Hopfield \\ JST merupakan sistem pemrosesan} informasi yang memiliki karakteristik mirip dengan jaringan syaraf biologi. JST memiliki 3 karakteristik utama, yaitu (Desiani dan Arhami, 2006):

\section{a. Arsitektur jaringan}

b. Algoritma jaringan

c. Fungsi aktivasi

Dalam penelitian ini jaringan Hopfield menggunakan fungsi aktivasi Fungsi Symetric Saturating Linear (satlins). Fungsi ini bernilai -1 jika inputnya kurang dari -1, dan bernilai 1 jika inputnya lebih dari 1 . Sedangkan jika nilai input terletak antara -1 dan 1, maka outputnya akan bernilai sama dengan nilai inputnya.

Metode ini dikembangkan oleh John Hopfield (ahli fisika, pemenang nobel 1982). Hopfield mempunyai sifat associative memory, ini berarti JST Hopfield seperti memori yang mampu menyimpan informasi yang pernah diberikan dan menampilkan kembali informasi tersebut apabila diminta. JST Hopfield juga bersifat High-fault tolerance yaitu kemampuan untuk memilih salah satu pola yang paling mirip dalam memorinya apabila pola yang diberikan tidak sama seperti salah satu pola dalam pembelajaran (Puspitaningrum, 2006).

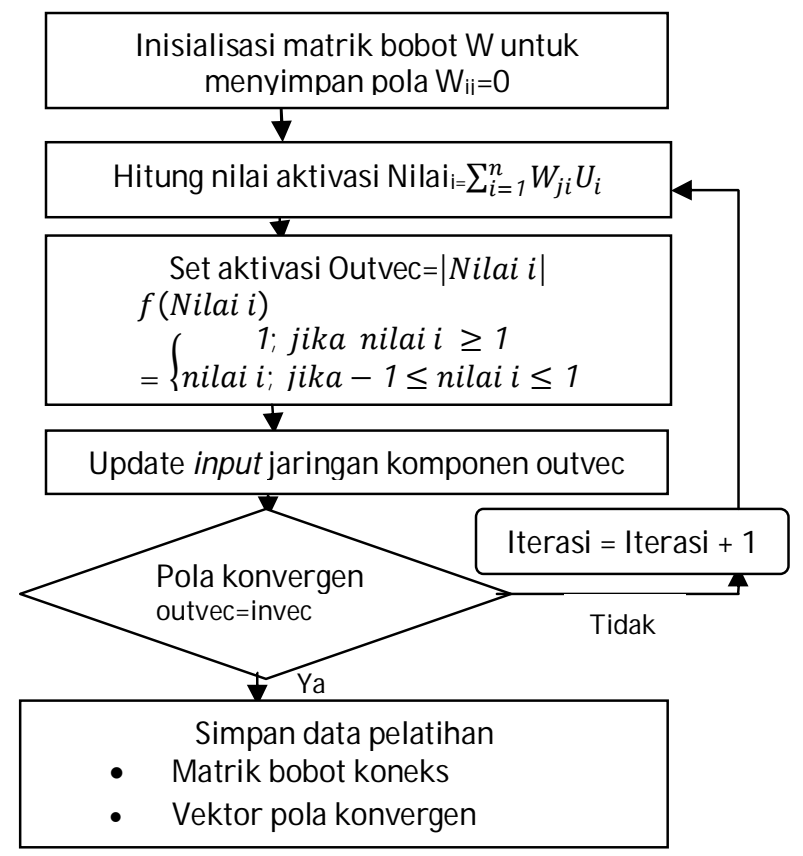

Gambar 1. Tahapan IST alqoritma Hopfield

\section{Metodologi}

Data cuaca yang digunakan dalam penelitian ini adalah suhu udara, kelembaban udara, arah angin, tekanan udara dan curah hujan dengan data jam-jaman pada bulan Mei, Juni, dan November 2012. Data cuaca ini merupakan data sekunder yang diperoleh dari Badan Meteorologi Klimatologi dan Geofisika (BMKG) Supadio Pontianak.

Data diolah melalui langkah berikut ini:

a. Penentuan Kriteria

Data cuaca untuk estimasi akan diklasifikasikan dalam 3 kriteria yaitu, keadaan cuaca cerah, berawan, dan hujan.

b. Penentuan Nilai Bipolar

Data input berupa 3 kriteria diubah menjadi fungsi bipolar yang menunjukkan nilai 1 dan $-1$.

c. Pembuatan Model Simulasi Algoritma

Pembuatan simulasi diperlukan untuk melakukan penyesuaian nilai bobot dengan nilai target (keluaran) yang diinginkan sehingga akan menghasilkan bobot optimal mencapai konvergen yang bisa mengenali data uji.

d. Validasi

Validasi ini dilakukan untuk mengetahui persentase tingkat ketepatan model yang telah diestimasi dengan cara keakuratan output yang dihasilkan. Rumus validasinya :

$$
\theta=\frac{\sum x_{t}}{\sum x_{o}} \times 100 \%
$$

dengan $\theta$ : Tingkat Ketepatan

$\mathrm{X}_{\mathrm{t}}$ : data hasil simulasi yang benar

$\mathrm{X}_{0}$ : data kondisi cuaca sebenarnya

Berikut ini adalah tabel nilai koefisien Tingkat Ketepatan.

Tabel 1 Skor Penilaian Data Hasil Validasi

\begin{tabular}{cc}
\hline Kategori & Nilai Tingkat Ketepatan \\
\hline Istimewa & $91-100$ \\
Sangat Baik & $81-90$ \\
Baik & $71-80$ \\
Cukup Baik & $61-70$ \\
Kurang Baik & $51-60$ \\
Sangat kurang & $<50$ \\
\hline
\end{tabular}

Sumber : Irmawan, 2011

\section{Hasil dan Diskusi}

\subsection{Penentuan Kriteria}

Data diklasifikasikan dalam 3 kriteria yaitu, keadaan cuaca cerah, berawan, dan hujan. Pembagian kriteria unsur cuaca diklasifikasikan menjadi 3 batasan kriteria yang diasumsikan berdasarkan dengan modus (nilai yang sering muncul) pada tiap jam bulan Mei, Juni, dan November. 
Tabel 2 Kriteria unsur Cuaca

\begin{tabular}{lccc}
\hline \multirow{2}{*}{ Unsur cuaca } & \multicolumn{3}{c}{ Keadaan Cuaca } \\
& Cerah & Berawan & Hujan \\
\hline Suhu & $>28^{\circ} \mathrm{C}$ & $25^{\circ} \mathrm{C}-28^{\circ} \mathrm{C}$ & $<25^{\circ} \mathrm{C}$ \\
Kelembaban & $<85 \%$ & $85 \%-90 \%$ & $>90 \%$ \\
& $>$ & $1006 \mathrm{mb}-$ & $<$ \\
Tekanan & $1008 \mathrm{mb}$ & $1008 \mathrm{mb}$ & $1006 \mathrm{mb}$ \\
Arah Angin & $<40^{\circ}$ & $40^{\circ}-50^{\circ}$ & $>50^{\circ}$ \\
\hline
\end{tabular}

Setelah data asli dibuat seperti dalam Tabel 2 , kemudian untuk memudahkan dalam proses komputasi diubah menjadi fungsi bipolar yang menunjukan nilai 1 dan -1 . Kriteria tersebut menjadi target yang dicapai. Sehingga dapat dibuat tabel sebagai berikut:

Tabel 3 Kriteria Unsur Cuaca Bipolar

\begin{tabular}{cccc}
\hline \multirow{2}{*}{ Unsur cuaca } & \multicolumn{3}{c}{ Keadaan Cuaca } \\
& Cerah & Hujan & Berawan \\
\hline Suhu & -1 & 1 & Pola \\
Kelembaban & 1 & -1 & selain \\
Tekanan & -1 & 1 & cerah dan \\
Arah Angin & 1 & -1 & hujan \\
\hline
\end{tabular}

\subsection{Pembuatan Simulasi Algoritma}

Model arsitektur Hopfield ini terdapat 4 (empat) unsur cuaca atau 4 neuron simetris, yaitu output yang ditargetkan harus sama dengan input. Untuk mencapai hasil yang optimal atau konvergen, output akan dijadikan inputan kembali.

Untuk pemilihan bobot, sebagai dasarnya jaringan syaraf tiruan Hopfield ini menggunakan pola matriks simetris dan berdiagonal 0 .

$$
\left[\begin{array}{llll}
0 & a & b & a \\
a & 0 & a & b \\
b & a & 0 & a \\
a & b & a & 0
\end{array}\right]
$$

Pemilihan bobot dengan teknik random untuk beberapa nilai bobot berpasangan. Pengambilan nilai dari 10 bobot yang telah di uji (Tabel 4) bobot yang dipilih adalah -8,1472 dan 9,0579 karena memiliki hasil simulasi dengan jumlah ketepatan terbesar dibandingkan bobot yang lain.

$$
\left[\begin{array}{cccc}
0 & -8,1472 & 9,0579 & -8,1472 \\
-8,1472 & 0 & -8,1472 & 9,0579 \\
9,0579 & -8,1472 & 0 & -8,1472 \\
-8,1472 & 9,0579 & -8,1472 & 0
\end{array}\right]
$$

Rata-rata bobot ini mencapai konvergen atau keadaan stabil pada iterasi atau langkah ke-18, artinya jaringan dianggap bisa mengenali dan mengingat pola yang dilatihkan. Untuk mencapai keadaan yang konvergen diperlukan energy lyapunov yang terdapat dalam pembobotannya.

Setelah data asli yang diubah dalam bentuk bipolar maka data pada Tabel 3 akan dijadikan sebagai input vector yang kemudian dikalikan dengan kolom-kolom bobot dengan diperoleh energi lyapunov. Hasil yang diperoleh kemudian akan dijadikan nilai bipolar kembali sehingga menghasilkan output vector $=$ input vector. Jadi ketika jaringan yang sudah dilatih diberikan input pola, JST Hopfield akan secara otomatis melakukan pengelompokan (clustering) sehingga nilai-nilai input yang serupa akan mengelompok pada pola output yang berdekatan atau sama.

\subsection{Estimasi Keadaan Cuaca}

Hasil estimasi pada bulan Mei, Juni, dan November dengan output model keadaan cuaca cerah, berawan, dan hujan sudah konvergen pada langkah atau iterasi 18 tetapi ada juga dari langkah 1 output sudah sama dengan input. Output yang dihasilkan cuaca cerah -1 1 -1 1 dan cuaca hujan 1 - 1 - 1 - 1 - Sedangkan kriteria keadaan cuaca berawan bukan dalam kondisi cerah dan hujan, sehingga pola yang tidak masuk dalam kriteria kondisi cerah dan hujan dianggap kriteria berawan. Ada beberapa pola kondisi berawan -1 -1 111 dan 1 -1 -1 1 . Pada realitanya bahwa berawan itu merupakan gabungan dari keadaan cuaca cerah dan hujan. Sebagian nilai kriteria keadaan cuaca berawan pada petang hari sampai dengan dini hari bersifat basah karena pada kondisi ini suhu udara menurun dengan kelembaban udara yang tinggi.

Tabel 4 Pemilihan Pembobotan

\begin{tabular}{cccccc}
\hline \multirow{2}{*}{ No } & \multicolumn{3}{c}{ Bobot } & \multicolumn{3}{c}{ Ketepatan } \\
\cline { 2 - 5 } & $\mathrm{a}$ & $\mathrm{b}$ & Mei & Juni & November \\
\hline 1 & $-8,1472$ & 9,0579 & $82 \%$ & $79 \%$ & $75 \%$ \\
2 & $-1,2699$ & 9,1338 & $66 \%$ & $65 \%$ & $71 \%$ \\
3 & $-9,5717$ & 4,8538 & $81 \%$ & $78 \%$ & $71 \%$ \\
4 & $-5,2176$ & 9,1574 & $78 \%$ & $79 \%$ & $72 \%$ \\
5 & $-7,4313$ & 3,9223 & $82 \%$ & $78 \%$ & $72 \%$ \\
6 & $-65,5741$ & 3,5712 & $82 \%$ & $79 \%$ & $74 \%$ \\
7 & $-27,8498$ & 54,6882 & $78 \%$ & $79 \%$ & $69 \%$ \\
8 & $-95,7507$ & 96,4889 & $82 \%$ & $78 \%$ & $72 \%$ \\
9 & $-792,2073$ & 959,4924 & $78 \%$ & $78 \%$ & $77 \%$ \\
10 & $-957,1669$ & 485,3756 & $82 \%$ & & \\
\hline
\end{tabular}


Hasil estimasi keadaan cuaca akan divalidasi gunanya untuk mengetahui persentase tingkat ketepatan model yang diestimasi dengan keakuratan output yang dihasilkan. Pada bulan Mei jumlah ketepatan yang dihasilkan $82 \%$, bulan Juni 79\% dan bulan November 75\% (Tabel 4). Kesalahan output model terjadi pada umumnya saat keadaan berawan tetapi data observasi menunjukkan keadaan cerah. Pada bulan Juni memiliki tingkat ketepatan yang lebih besar dibandingkan pada bulan November. Hal ini diduga akibat kondisi cuaca pada bulan November memiliki hari hujan yang lebih banyak (30 hari) dibandingkan bulan Juni (6 hari). Keadaan hujan sulit diestimasi karena terkadang terjadi pada suhu yang tinggi dan juga terjadi pada suhu yang rendah.

Sebagai contoh kasus, pada data observasi pukul 13.00 hari ke-4 bulan November 2012 menunjukkan cuaca hujan (suhu $28,4{ }^{\circ} \mathrm{C}$, kelembaban udara 78\%, tekanan udara 1007,8 $\mathrm{mb}$, dan arah angin 42) namun hasil model memperlihatkan cuaca cerah. Pada kondisi yang lain pukul 21.00 terjadi hujan (suhu $24,8{ }^{\circ} \mathrm{C}$, kelembaban 98\%, tekanan udara 1011,2 mb, dan arah angin 60) dengan hasil model menunjukkan kesesuaian pada kondisi yang sebenarnya.

\section{Kesimpulan}

Berdasarkan penelitian yang telah dilakukan, maka dapat disimpulkan JST algoritma Hopfield dapat digunakan untuk estimasi keadaan cuaca menggunakan 4 unsur cuaca yaitu suhu udara, kelembaban udara, tekanan udara, dan arah angin. Untuk keadaan cuaca di Kota Pontianak memiliki tingkat ketepatan pada bulan Mei dengan kategori sangat baik (82\%), Juni baik (79\%), dan November baik (75\%).

Untuk kriteria keadaan cuaca cerah, output yang dihasilkan sama dengan nilai yang menuju cerah $-1 \quad 1 \quad-1$ 1. Demikian dengan kriteria keadaan cuaca hujan, output sama dengan nilai yang menuju hujan $1-11$-1. Sedangkan untuk kriteria keadaan cuaca berawan output bipolar memiliki beberapa pola yaitu, -1 -1 1 1, dan 1 -1 -1 1. Kriteria keadaan cuaca berawan ini merupakan gabungan keadaan cerah dan hujan.

\section{Pustaka}

Asdak C., 1995, Hidrologi dan Pengelolaan Daerah Aliran Sungai, Gajah Mada University Press, Yogyakarta.

Arpan, F; Galuh, D; Sudjarwali., 2004, Kajian Meteorologi Hubungan Antara Hujan UnsurUnsur Cuaca, Majalah Geografi Indonesia Vol 18 No.2 Jakarta.
Desiani A dan Arhami M., 2006, Konsep Kercedasan Buatan ,penerbit ANDI Yogyakarta.

Ernawati S., 2009, Aplikasi Hopfield Neural Network Untuk Prakiraan Cuaca, Dokumen 1347_Volume_10_Nomor_2 November_2009, Stasiun Klimatologi Semarang. Hal: 151-175

Hasanah N., 2007, Penyelesaian Shortest Path Problem Dengan Jaringan Saraf Tiruan Hopfield, Seminar Nasional Sistem dan Informatika, Bali. Hal: 276-281

Horn, H,L dan Trewartha, T, G., 1995, Pengantar Iklim, Edisi Kelima, Gadjah Mada University Press, Yogyakarta.

Irmawan D, Herusantoso, K., 2011, Penerapan Logika Fuzzy Sebagai Sistem Pendukung Keputusan Prakiraan Cuaca, e-Indonesia Initiative 2011 (eII2011) Konferensi Teknologi Informasi dan Komunikasi untuk Indonesia 14-15 Juni 2011, Bandung. Hal: 214-223

Puspitaningrum D., 2006, Pengantar Jaringan Syaraf Tiruan, Penerbit Andi 